\title{
An Empirical Model for Successful Collaborative Design Towards Sustainable Project Development
}

\author{
Yani Rahmawati ${ }^{1}$, Christiono Utomo ${ }^{1}$, Nadjadji Anwar ${ }^{1}$, Purwanita Setijanti $^{1}$ \& Cahyono Bintang Nurcahyo ${ }^{1}$ \\ ${ }^{1}$ Institut Teknologi Sepuluh Nopember (ITS), Surabaya, Indonesia \\ Correspondence: Yani Rahmawati, Civil Engineering Department, Institut Teknologi Sepuluh Nopember, \\ Kampus ITS Sukolilo 60111, Surabaya, East Java, Indonesia. E-mail: yanirahmawati2012@gmail.com
}

Received: November 1, 2013 Accepted: December 27, 2013 Online Published: February 19, 2014

doi:10.5539/jsd.v7n2p1

URL: http://dx.doi.org/10.5539/jsd.v7n2p1

\begin{abstract}
Building design is developed into complexities, especially because of the emergence needs on applying a concept of sustainability. Aesthetic and engineering systems are no longer as main consideration in a design production process. Collaboration is needed to facilitate the integration of multiple knowledge and participants in a design process. In the process, multiple experts are required for achieving the best design. This paper purposes to discover issues and solutions as the important factors of collaborative design. Literature study is applied to determine the factors which are physical, technical, and social factors. They are found as three main aspects to be considered in supporting successful collaborative design. It is also found that recently, research in this area is directing for developing social factors as main issue. Factor analysis is also used as methodology to identify and analyze the similarities and interdependencies between factors. Analysis of data which is gained from designers and experts in Indonesia discovers that the three factors are reduced into two factors. The model of successful collaborative design is developed based on two findings in this research, that is not only conceptually but also empirically.
\end{abstract}

Keywords: collaborative design, multi-discipline design, sustainable project development

\section{Introduction}

Implementation of sustainability concept in a project development causes a building design into complexities, and it causes the need to involve multiple experts to accomplish the design. Stasinopoulos et al. (2009) described that building systems is not the only aspect that need to be considered in building design. The impact of building to sustainability as whole system of built environment is another important factor. It is supported by Wang et al. (2010) whom stated that long-term environmental and economical benefits of urban growth and development are important to be considered in the concept of building design. Based on review, it is found that collaborative design is an essential approach to facilitate multi participants in a design process (Kalay et al., 1998), as Kvan (2000) found that various experts are involved in design process to acquire suitable knowledge. They were able to work together simultaneously in integrating their expertise to gain best design as best shared solutions through collaborative design. This achievement will support the sustainability of project development. Related with this statement, Utomo and Rahmawati (2012) had found that in developing sustainable project development, especially in vertical housing, collaborative design has important role in supporting it.

Researches in collaborative design are mainly discussing about the achievement of successfulness (Rahmawati et al., 2013). Most of them described issues which are contributed to failure in achieving the most appropriate design. The inventions of methods, tools, or systems which supported collaboration in design process are also discussed in the researches. Due to the important need of successful design in supporting sustainable project development, this research is conducted to discover factors which support successful collaboration. It identifies issues and solutions that have been developed in previous research. Literature review is used as methodology in this research. There are three main processes which are used to implement the methodology (Levy \& Ellis, 2006), that consist of collecting papers, analyzing papers, and synthesizing papers. In applying literature review, researches in this area are collected and classified based on similarity of issues and solutions that have been described and purposed. And then it is continued with synthesizing process by comparing and combining the classified issues and solutions. The discovered factors that are classified in each group will be determined as 
supported factors. In which it can be used as guidance or knowledge in achieving successful collaborative design. The result also gives identification and prediction of future research direction.

\section{Conceptual Background}

Definition of collaborative design is illustrated in Figure 1, which is adopted from Rahmawati et al. (2013a). Collaboration has similar meaning with integration (Schmidt, 1994; Bucciarelli, 2002). There are two main aspects that need to be integrated, which are participants to reveal best knowledge (Vivacqua et al., 2011) and also design objects that consist of data and knowledge (Gabriel \& Maher, 2002). The integration of both aspects will support negotiation, in which it will lead to carry the achievement of optimum design as best shared solution through the process of decision making (Zha \& Du, 2006) and problem solving (Utomo et al., 2009). Ding (2008) stated that optimum design of sustainable urban development can be resulted from the integration concept of building's aesthetics, structures, utilities, functions, and its impacts to sustainability. Moreover, Besley and Ghatak (2010) purposed a concept that sustainability also has to be reached by supporting growth of urban economics, that is gained from best and highest value of the building itself in attaining optimum revenue. All those criteria need to be considered in achieving long term project development (Heising, 2012). Based on this description, it can be concluded that collaborative design is an important approach to achieve sustainable project development. Comprehension study about it is necessary, especially in terms of issues and approaches that has been revealed and developed, in order to enrich information that is essential in conducting successful collaboration.

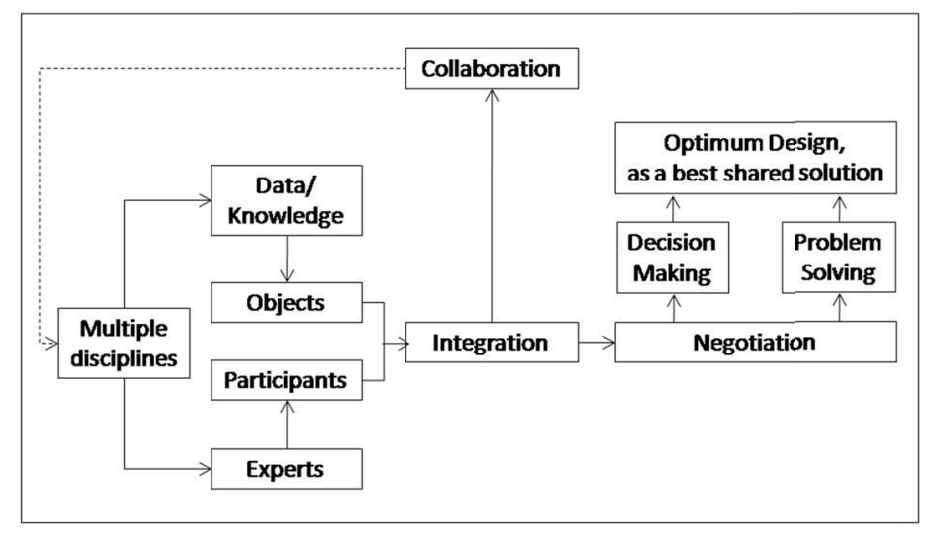

Figure 1. Illustration of collaborative design process (Rahmawati et al., 2013a)

\section{Result and Discussion}

\subsection{Supported Factors of Successful Collaborative Design}

Developing tools and systems for supporting collaboration is main motivation of most research in collaborative design (Kvan \& Candy, 2000; Cheng, 2003). Analyzing weakness and strength of approaches that has been purposed is important, due to the need of achieving optimum design in multi participants design process to achieve sustainability (The Natural Edge Project, 2007; Melchert, 2007). Information that is gained from analysis can be concerned to lead the achievement. In reviewing research with main topic, researches were classified based on the similarity of issues and solutions which were purposed. As shown in Figure 2, they can be grouped into three main groups which consist of physical approach, technical approach, and social approach.

Physical issue is determined as first group. Studies in this area have similar issues related with difficulties in conducting physical meeting between participants whom have to simultaneously work together in design process. Each participant has different time and place availabilities, which caused un-efficient collaboration process. Some studies were conducted to deal with this issue. Kvan (2000) and Wang et al. (2002) found that successful collaborative design can be achieved through computer-based tools and systems, where participants able to work in one area even though they are located in different places. Based from this important factor, researchers are then developing to invent tools and systems by considering the development of information and communication technology (ICT) to create media which support virtual collaboration between participants (Oztok \& Ordener, 2007; Ha \& Kim, 2008). 
Physical issue and approach was then developing into the second group, which is related with technical issue. On its development, collaborative design issue is emerging to the difficulties in integrating design process. The difficulties are caused by the appearance of conflicts that are resulted from different perceptions between participants. Some studies developed technical approach by applying knowledge management (KM) to create shared understanding environment between participants (Saad \& Maher, 1995). Furthermore, this technical issue is then developing into issue related with difficulties in integrating participants because of the appearance of social issues. Researches related with social issues are grouped in the third group. Some researches was then developed by considering social factors in collaboration process in order to achieve best shared goal from the experts (Kolarevic et al., 2000; Weinel et al., 2011).

\begin{tabular}{|c|c|}
\hline \multicolumn{2}{|c|}{ Main purpose of collaborative design researches : } \\
Supporting successful collaborative design process
\end{tabular}

Figure 2. Conceptual figure of three main factors in supporting successful collaborative design (Adopted and developed from Rahmawati et al., 2013b)

\subsection{Collaborative Design Research Development}

There are three categories of issues and solutions which have been developed. They are categorized as physical approaches, technical approaches, and social approaches. Each category has different contents, but all groups have one similar purpose, that is to support the achievement of successful collaborative design.

\subsubsection{Physical Approaches}

Physical approach contains of solutions to face or avoid physical issues related with time and place availabilities of participants. These issues can be avoided by providing virtual workspace in collaborative design process (Kvan, 2000). In line with Kvan (2000), Woo et al. (2001) also found that workspace can be used to face physical issues by providing system that able to record the design process and also system that able to support each participant in modifying design object. Some other tools and systems are used and developed to deal with physical issue, which consisted of internet and web application (Wang et al., 2002); Electronic Cocktail Napkin, PHIDIAS Hypermedia System, Construction Kit Builder, Hypersketch Prototype, and Digital Design Sketchbooks and Mobile (Gross et al., 1998); and also Virtual Design Studio which is known as VDS (Kolarevic et al., 2000).

Another way was also purposed by Lee and Gilleard (2002), by developing Hypermedia system to create virtual discussion tables with purpose to facilitate activities in exposing data or information from participants. Computer Aided Design (CAD) also has ability to facilitate the physical collaboration ( $\mathrm{Li}$ et al., 2005). According to Nam 
and Wright (2001), CAD is able to support a shared 3D workspace in facilitating the activities of building and editing virtual 3D Model in design process. Verheij and Augenbroe (2006) also purposed model to facilitate the mediating process by integrating Project Planning Process Model (PPPM) with web-enabled B2B facility. This integrated model can be used to build virtual workspace with purpose to manage the physical collaboration of participants along with different time and place availability.

\subsubsection{Technical Approach}

There are some weaknesses in the use of shared workspace. Conflict is the main issue that emerges as weakness of shared workspace, in which it leads to unfinished design (Ren et al., 2011). The divergence of backgrounds and expertise caused the appearance of different perception between participants ( $\mathrm{Gu}$ et al., 2005), that able to generate conflicts. This issue influences decision making in design process (Utomo \& Idrus, 2011). Building shared understanding environment is essential in order to avoid conflicts (Simoff \& Maher, 2000).

Shared understanding can be achieved by managing data and knowledge during design process (Chiu \& Lan, 2005). As Kvan and Candy (2000) had described, shared understanding can be achieved by integrating data and knowledge through KM. Technical approach contains of issues and solutions that related with the achievement of shared understanding between participants by using $\mathrm{KM}$, in which the purpose is mostly to technically collaborate the design process. Information about design development, such as design alternatives, design criteria, descriptions or narratives and also decisions, is defined as knowledge in collaborative design. This knowledge is need to be managed to achieve shared understanding, in which it will mainly support the integration process (Detienne, 2006) and also negotiation process (Lottaz et al., 2000).

$\mathrm{KM}$ is useful to maintain data integration in supporting problem solving and decision making (Veeramani et al., 1998). Design objects classification (Huifen et al., 2003); information patterns revelation using data mining (Chiu \& Lan, 2005); and reducing semantic conflicts by library building (Gu et al., 2005) are some systems that have been developed. Saad and Maher (1995) stated that KM is able to support the achievement of shared understanding environment. Based from this approach, Shared Design Thinking Process Model is purposed (Du et al., 2011). Besides shared understanding, facilities that support modification of design object are also essential in collaborating design process (Leeuwen \& Fridqvist, 2006). Related with these findings, information modeling of design object that support decision-making activities has been developed by Plume and Mitchell (2007).

Shared understanding environment can also be achieved by understanding the process of design development completely. Story of design process and the chronologies of problems solved are necessary to be recognized by all participants. An exploratory research conducted by Gabriel and Maher (2002) found that the important factor is the application of textual communication in design process and also the provision of recording system, where communication between participants were stored in the form of textual communication. It is also found that textual communication able to made participants easier in understanding design development. To support shared understanding, Lahti et al. (2004) found the arrangement and organization of tasks, which are also need to be considered in the process. It is also found that collaboration is able to be done through Virtual Design Studio (VDS), but successfulness can only be achieved if social infrastructure in design team is considered. Both physical and technical approaches that have been developed before are no longer become the most important factors. The weaknesses of technical approaches, that only have ability to collaborate design objects without ability in collaborating participants, are leading to consider the social factors in the process. The collaboration is involving participants as well, which makes factors related with participants and design teams are essential to be concerned (Girard \& Robin, 2006).

\subsubsection{Social Approach}

Social approach consists of issues and solutions related with participants and design team that are used with purpose to gain best knowledge from participants (Vivacqua et al., 2011) and also to achieve best shared solution as design goal (Lu et al., 2007). Social issues are caused by diverse participants' behaviors (Peng, 1994) that influence the appearance of inadequate communication between participants. The provision of communication facilities, which is mostly ICT-based tools and system, can also generate social issues which lead to influence the design team (Cheng, 2003). In supporting collaboration of participants, Patel et al. (2012) suggested seven main factors that need to be concerned, that consists of context, support, tasks, interaction process, teams, individuals, and overarching factors. Other research found that collaboration can be generated through integrated design team (Ping et al., 2011), in which it is necessary to create teamwork at the first step of collaboration in order to build integrated teamwork. The integration will lead to effective design process (Lin et al., 2008). Related with its importance, coordination of task and its interdependencies during the process need to be considered in realizing 
integrated team work (Detienne, 2006; Rahmawati et al, 2012a). Girard and Robin (2006) also found that teamwork is an important factors supporting collaboration.

Another social factor that needs to be considered is the influence of participants' attitudes to design task (Weinel et al., 2011). Related with this finding, participant's behavior in decision making process is need to be concerned, because it also affects the outcomes of design process, where best integrated solutions cannot be reached (Vivacqua et al., 2011). According to McMahon and Bhamra (2012) the aspect of social sustainability that is achieved through collaboration skill is important in supporting the process. Teamwork, compromise and negotiation, cultural and social diversity, participation, and also communication are collaboration skill that are needed. Based from previous description, it can be concluded that consideration to social factors are also needed in order to achieve best shared goal. It is gained through well process of decision making from best knowledge that has been revealed from the experts. Based on analysis, it can be concluded that social factors determine successfulness and effectiveness of collaboration.

\subsection{Future Research Direction on Collaborative Design}

To identify and discover future research direction, the compilation of similar issues and solutions in three approaches are arranged historically. The researches in each group are organized according to the year of publication. Each group will also synthesized by discovering similarities and differences of one group compares to others, in order to discover and identify development of researches. Based on the process, it is found that the development of each group is different. Figure 3 described the development flow of collaborative design researches. Researches in each classification are mostly developed in similar years, where the range of one research to others is not too far. Based on analysis, it is found that each group also has weakness, in which the weaknesses of one group become input for other group to develop collaborative design researches.

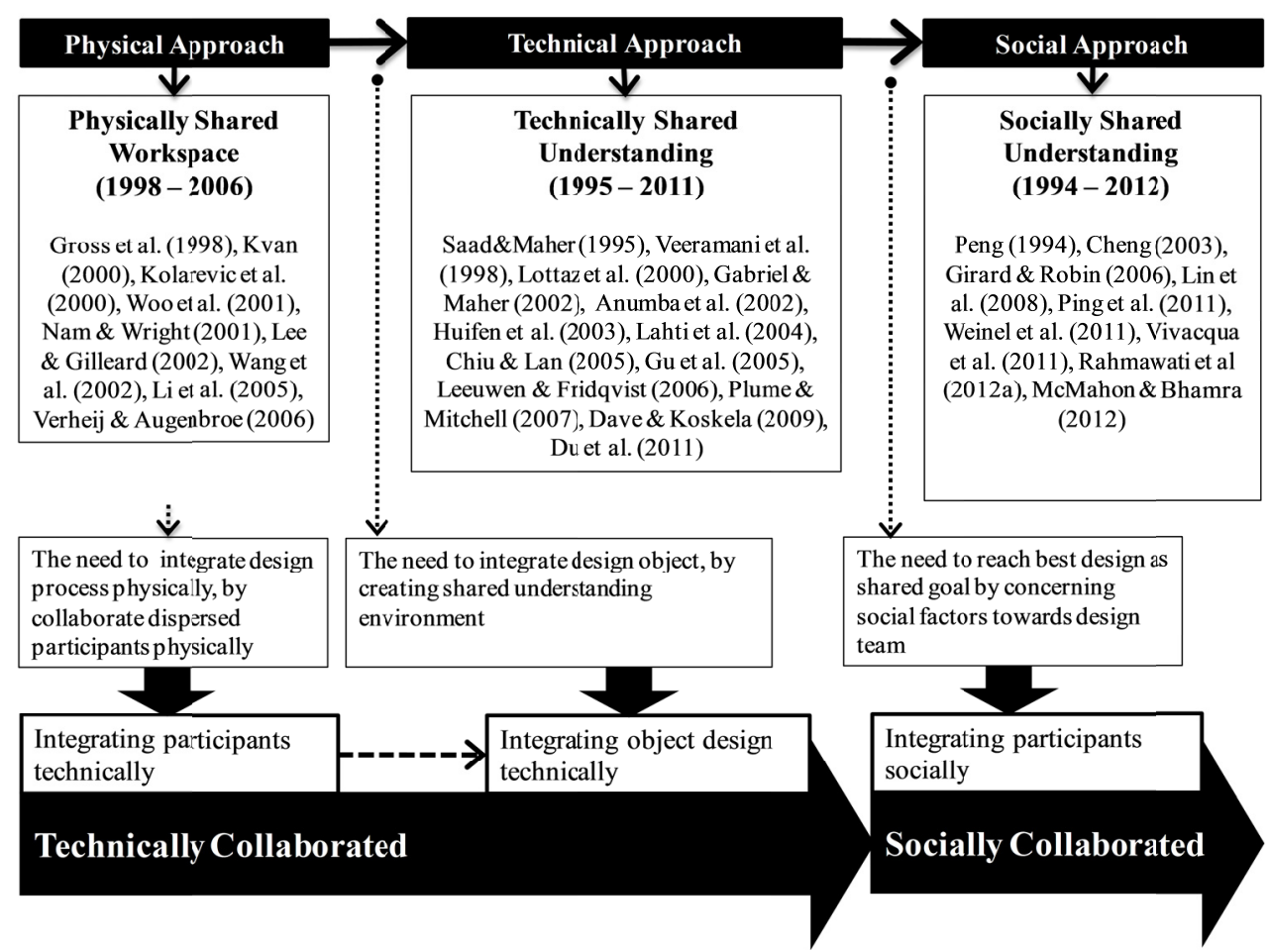

Figure 3. Conceptual figure of future research direction in collaborative design (Adopted and developed from Rahmawati et al., 2013a)

Research with main topic of physical approach is developed earlier than others, because most of the papers were published in the earlier year of 2000. It is also because the issue which was raised is more basic to other, which is the important need to collaborate participants physically. And the purposed solution is the invention of shared workspace as a media which facilitated participants to work together virtually. Most of invented methods, tools, or systems in physical approach were developed based on the creation of shared workspace (Gross et al., 1998; Kolarevic et al., 2000; Woo et al., 2001; Kamel, 1999; Nam \& Wright, 2001), which is a media that facilitating 
the integration of dispersed participants. It is developed based on the need to integrate participants physically, where participants are able to work together without facing difficulties related with time and place availabilities. But some research found that shared workspace has some weakness in supporting the successful collaborative design (Gabriel \& Maher, 2002), that is difficulties in integrating design objects.

The issues develop into the appearance of conflicts that are caused by misunderstanding between participants. It is because of each participant did not understand design development, in which participants cannot recognize any objects or concept of design that had been changed, modified, done and shared by other participants. According to research conducted by Gabriel and Maher (2002), this issue can be solved by implementing KM in collaborative design process. KM can be applied by providing systems and tools that able to record the design process, where each participant is able to discover and understand the design development and also the reason behind it. Issues related with the integration of design process and design object are main issues that are developed in technical approach. Some technical approaches that are based on KM are developed (Plume \& Mitchell, 2007; Dave \& Koskela, 2009; Veeramani et al., 1998). Main purpose of the approaches is to manage data and to achieve similar perception between participants. The approaches consist of building systems in revealing data of design development (Chiu \& Lan, 2005), building library to classify design object (Gu et al., 2005), and also storing data changes (Huifen et al., 2003). Shared understanding can be achieved in condition that all design development process is recorded, so that each participant is able to trace design developments which have been done by others. This facility will made participants are able to understand other participant's thought.

Limited environment in virtual workspace causes lack of social interaction in collaborative design process. Even though there are some endeavors in supporting the virtual work by using technical approach in achieving shared understanding environment between participants, some research found that it can only support the integration of design object, and it cannot integrate the participants (Kolarevic, 2000; Lahti et al., 2004). It is important to consider the social factor (Rahmawati et al., 2012a), because it can affect to the effectiveness of collaboration process which will lead to unsolved problems, insufficient design, and unfinished design process (Weinel et al., 2011). Based on this issue development, research is then grown and developed to consider social approach. The social approach consisted of teamwork management, communication, culture, organization, individual behavior, etc. There are some researches which consider in combining technical and social approaches ( $\mathrm{Lu}$ et al., 2000; $\mathrm{Lu}$ et al., 2007). It can be predicted that research in the area of collaborative design is leading to consider the social approach in achieving the optimum design. It not only can be used as a basic foundation to run the process effectively, it also able to support in revealing and integrating best solution from experts.

\section{Empirical Study of Collaborative Design in Indonesia}

Table 1. Factors of Successful Collaborative Design

\begin{tabular}{|c|c|c|c|}
\hline Factors & Sub-factors & Source & Description \\
\hline $\begin{array}{l}\text { A. Physical } \\
\text { Factors }\end{array}$ & $\begin{array}{l}\text { 1. Information \& } \\
\text { Communication } \\
\text { Technology (ICT) }\end{array}$ & $\begin{array}{l}\text { Kvan (2000), Woo et } \\
\text { al. (2001), Gross et al. } \\
\text { (1998) }\end{array}$ & $\begin{array}{l}\text { ICT-based tools and systems that need to } \\
\text { be applied to support virtual meeting and } \\
\text { to avoid time-place availabilities issues }\end{array}$ \\
\hline \multirow[t]{2}{*}{$\begin{array}{l}\text { B. Technical } \\
\text { Factors }\end{array}$} & 2. Software & Anumba et al. (2002) & $\begin{array}{l}\text { The used of similar software that need to } \\
\text { be applied as an approach to support the } \\
\text { integration of design process }\end{array}$ \\
\hline & 3. Perception & $\begin{array}{l}\text { Gabriel \& Maher } \\
(2002)\end{array}$ & $\begin{array}{l}\text { The achievement of similar perception } \\
\text { through shared understanding environment } \\
\text { in collaborative design process }\end{array}$ \\
\hline \multirow[t]{2}{*}{$\begin{array}{l}\text { C. Social } \\
\text { Factors }\end{array}$} & 4. Personality & Vivacqua et al. (2011) & $\begin{array}{l}\text { Consideration of participants' personality } \\
\text { which influences design team and process }\end{array}$ \\
\hline & $\begin{array}{l}\text { 5. Social } \\
\text { Relationship }\end{array}$ & $\begin{array}{l}\text { Charnley et al. (2010), } \\
\text { Girard \& Robin (2006) }\end{array}$ & $\begin{array}{l}\text { Consideration of social relationship } \\
\text { between participants in design team }\end{array}$ \\
\hline
\end{tabular}

The concept of collaborative design is also applied at design process in Indonesia (Rahmawati et al., 2013b), which is concluded from the indicators of collaborative design that are mostly found in design process. Physical factors, technical factors, and social factors are found to be important factors in supporting collaborative design. 
The study is continued to identify and analyze similarities and interdependencies of those three factors, and factor analysis is used as methodology. The factors are asked to designers and experts whom have experience to work at multi participants design process in Indonesia. There are five main variables which represent the factors, as presented in Table 1.

ICT is determined as variable of physical factor in this study, because main purpose of physical factor is to avoid difficulties in conducting meeting by providing ICT-based tools and systems (Kvan, 2000; Woo et al., 2001). Software and perception are determined as variables of technical factors. Those factors relate with KM that support the integration of design process. Both of software and perception are two important variables in leading successful collaborative design through KM. The use of similar software in design process aims to avoid difficulties in modifying design (Anumba et al., 2002), where object design will easier to be integrated in design process. The appearance of similar perception, especially related with design development, will lead to the achievement of shared understanding between participants (Gabriel \& Maher, 2002).

There are also two variables that are determined as variables in social factors. The variables are personality and social relationship. In the preliminary study of this research, most of respondents stated that the experience of each participant in working together as team at design process is used as main reason to form design team. This statement is one of factor that supports collaborative design (Girard \& Robin, 2006). According to Charnley et al. (2010), the used of design team whom has worked together in other design project before is because the appearance of social relationship in the team. Additional time in recognizing and understanding each participant and his/her works in design team will not be necessary, because participants had known each other before. Personality of each participant will also important to be considered in forming design team (Vivacqua et al., 2011). Related with the influence of personality in collaborative design, most respondents said that stubborn or uncompromised participants are difficult to be maintained or be faced with.

\subsection{Characteristic of Respondents}

There are 36 respondents whom have experiences as participants at collaborative design process in Indonesia. The data that will be analyzed to achieve the research's purpose is collected through questionnaires that are given to respondents. The characteristics of respondents are presented in Figure 4, Figure 5, and Figure 6. Figure 4 presents the role of each respondent in design process. Kalay et al. (1998) mentioned six types of participants whom mostly involved in collaborative design process. They are owner, specification specialists, architect, civil engineer, mechanical/electrical engineer, and also interior designer. Respondents mostly have role as architect in collaborative design process (43\%). Other roles which are mostly involved at design process in Indonesia are interior consultant $(10 \%)$, mechanical electrical consultant (2\%), building structure consultant (26\%), public owner (17\%), and private owner (2\%). Those respondents mostly have experience to be involved in collaborative design for more than 15 years (48\%), whom the rest of them have experience for 10-15 years (26\%), 5-10 years $(13 \%)$, and below 5 years $(13 \%)$.

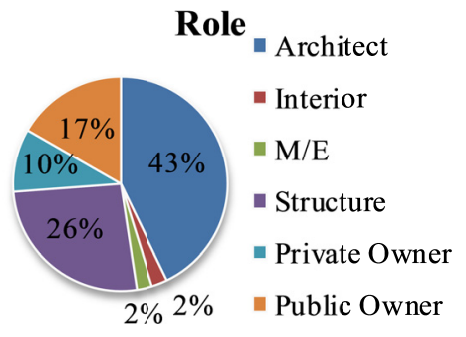

Figure 4. Role of Respondents in design process 


\section{Experience}

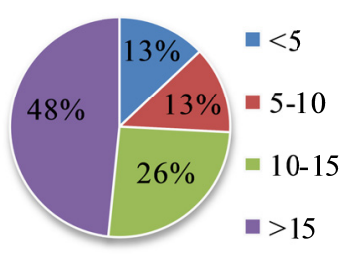

Figure 5. Experience of Respondents in design process

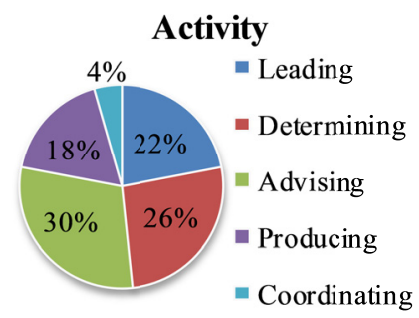

Figure 6. Activity of Respondents in design process

There are five activities that mostly become responsibilities of respondents, such as leading the design process from beginning till end (22\%), determining decisions of design development $(26 \%)$, sharing and giving advice of design related with each participant's expertise $(30 \%)$, producing design $(18 \%)$, and also coordinating design process (4\%). Sharing and giving advice is the most responsibility of respondents, it is because respondents whom are involved in this research are mostly consultants. Some of the consultants are also have responsibility in determining decisions of design, which is it is because the respondents are mostly architect (43\%).

\subsection{Factor Analysis}

Factor analysis indicates that the sample of this research is adequate, in which the value of Kaiser-Meyer-Olkin (KMO) measure of sampling adequacy has to be more than 0.5 (Field, 2000). The KMO is 0.544 , and the Bartlett test also indicates highly significant value $(\mathrm{p}<0.001)$. This result shows that factor analysis is appropriate to be used as methodology to analyze collected data in identifying similarities between factors. Five factors that are analyzed using factor analysis are classified into two factors. Four factors of five are grouped into one factor. As presented on Table 2, the factors that grouped into one are software, perception, personality, and also social relationship. Based on the purpose of factor analysis, it can be described that those four factors have similarity and interdependencies each other. The other factor, that is ICT, grouped alone in factor 1. Based on factor analysis purposes, it also can be described that there are no factors which have similarity and interdependencies with ICT. The ICT stands alone as factor 1.

Table 2. Factors resulted from factor analysis

\begin{tabular}{ll}
\hline Factor 1 & Factor 2 \\
\hline ICT & Software \\
& Perception \\
& Personality \\
& Social Relationship \\
\hline
\end{tabular}

Main reason of each factor in supporting collaborative design is to maintain the integration in design process (Rahmawati et al., 2013a), that can be realized through the integration of design objects and design participants or teams. Reviews on collaborative design research found that design participants should be integrated not only 
technically but also socially. Technically integration of participants can be achieved through endorsement of ICT-based tools and systems, as Gross et al. (1998) had discovered that ICT able to support the integration of participants through virtual meeting. Most of respondents declared that technological issue is the most essential issue at collaborative design process in Indonesia. Based from interviewed to all respondents, the ICT that are applied in Indonesia restricted to the use of phone (75\%), facsimile (53.13\%), email (84.38\%), recording tools $(6.25 \%)$, virtual studio (3.13\%), and teleconference (9.38\%). The result is presented on Figure 7.

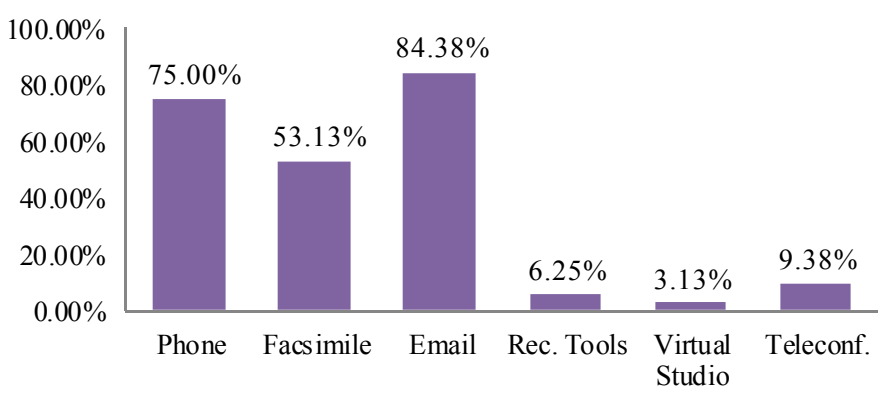

Figure 7. Technology used at collaborative design process in Indonesia

The use of email is dominating in supporting collaborative design in Indonesia, which is shown that $84.38 \%$ respondents are using email to support the design process. Beside email, phone and facsimile are becoming tools that are mostly used. Collaborative design is recently developed in Indonesia (Rahmawati et al., 2013b), and the limitation used of supported tools and systems made the successful is hard to be achieved. Issues related with time and place availabilities of participants in conducting physical meeting are still becoming essential issue in Indonesia. Physical approach is vital due to the appearance need of technology in design process. Rahmawati et al. (2013) found that ICT-based tools and systems became the most important factor amongst others in Indonesia.

Respondents have similar perception with study resulted by Kvan (2000), that is technology through ICT-based tools and systems is the most important factors. In which it is also akin with Woo et al. (2001) and Gross et al. (1998). Kolarevic et al. (2000) also proofed that the ICT able to support physical integration of participants, but it is also found the ICT cannot support the integration of design process, related with design object and also design participants as teamwork. Based on this analysis, it can be described the result of factor analysis. ICT is grouped as the only factor in Factor 1, it is because ICT does not have similarities with other factors. This finding is related with finding resulted by Kolarevic et al. (2000), which is found that the ICT can only support the physical integration.

Other four factors of successful collaborative design accumulate to Factor 2. The factors are related with integration of design process. The involvement of multi disciplines participants in design process caused the use of divergent software. This issue will lead to problems in modifying design process (Anumba et al., 2002). Qin et al. (2003) suggested to use same software in the process to avoid the problems. This approach supports the invention of systems that capable to accommodate modification process of design object in one single software (Gu et al., 2011; Plume \& Mitchell, 2007; Chiu \& Lan, 2005). Akin with software, the role of perception is to support the integration of design process as well, especially the design object. Similar perception will carry negotiation process (Ren et al., 2011), in which it will also lead to support the decision making process of design (McCall \& Johnson, 1997). The achievement of similar perception is also as important as the used of similar software in the process. Both factors have role in collaborating design process with main consideration to design object.

Other two factors, which are personality and social relationship, are also grouped in Factor 2. Personality and social relationship are factors that support the integration of participants in design process, which have capabilities in influencing design as final result (Ping et al., 2011). Having similar role with software and perception, both personality and social relationship are able to support the integration process with main consideration to participants. Some research has found that collaboration of participants is also needed (Patel et al., 2012). Inflexible, level of awareness and attention, and maturity are some personality's factors that influence 
the collaboration (Vivacqua et al., 2011). In supporting the collaboration, the social relationship, such as experience in working together, also has to be considered (Girard \& Robin, 2006).

Rahmawati et al. (2013a) had conceptually separated those four factors into two main factors, but the result of factor analysis illustrates different finding. Result indicates that there are similarities and interdependencies between four factors, so that they gather into one factor. Gabriel and Maher (2002) found that in supporting collaboration, technical factors through KM application are the only important factor in the process. During the process, the role of technical factors is separately defined with other factors, including the social factors. Related with this, Vivacqua et al. (2011) had different finding, which indicated that the collaboration process are also need social factors. Social factors are important as well in the process.

Vivacqua et al. (2011) and Gabriel and Maher (2002) have different point of view. Gabriel and Maher (2002) concerned to the collaboration of design object that was based on the important need of shared understanding achievement, meanwhile Vivacqua et al. (2011) concerned to the participants that was based on the influences of participants to the process which will lead to persuade result. But both findings have one general purpose which is supporting the collaboration process. It is reasonable if factors of both technical and social accumulate and become one factor. It can be explained that all those factors have similar importance in the process. Social factors are developed because of lack consideration of participants' collaboration in the process, while technical factors were mostly developed before. It can be also concluded that in conducting successful collaboration process, technical factors cannot stand alone; it also needs the social factors to achieve best collaboration. Both factors can be combined to technical-social factors.

Some research also found similar findings of technical-social factors (Lu et al., 2000; 2007; Rahmawati et al., 2012b). Lu et al. (2000) developed socio-technical framework, which described conceptual model of the correlation between social and technical aspects in influencing collaborative design process. The conceptual model was then also developed by Lu et al. (2007) with purpose to integrate technical and social approaches in facilitating the achievement of successfulness. This development was underlying research that conducted by Rahmawati et al. (2012b). Through literature study of collaborative design research, Rahmawati et al. (2012b) found factors that support collaborative design. Based on the purposes, factors can be grouped into two main supported factors, which are technical and social factors. Both factors were then combined and named as socio-technical factors.

\subsection{Empirical Model of Successful Collaborative Design}

Based on the analysis, empirical model of successful collaborative design is illustrated on Figure 8. There are two important factors to successfulness. First factor is physical factor, which can be measured or indicated by the use of ICT-based tools and systems. Second factors is technical-social factors, that can be indicated by the use of similar software in the process, the achievement of similar perception, and also consideration to personality and social relationship in team design.

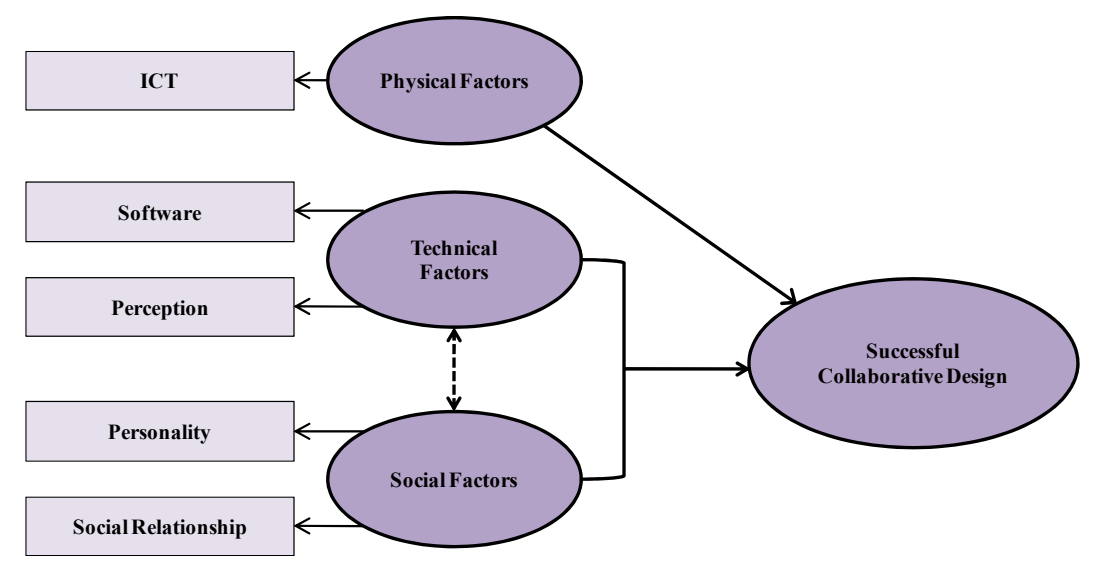

Figure 8. Empirical model of successful collaborative design

\section{Conclusion}

Literature study had found important factors of successful collaborative design in supporting design process of sustainable project development. Based on the development of issues and approaches in collaborative design, the 
factors can be classified into three main factors, which consist of physical, technical, and social factors. The factors are then analyzed to identify similarities and interdependencies between each other by using factor analysis. The result indicates that technical factors and social factors have similarities, so that the factors become physical factors and also technical-social factors. Physical factors can be indicated by the application of ICT-based tools and system. Technical-social factors can be indicated by similar software and perception in the process, and also consideration of personality and social relationship of participants in design team.

\section{Acknowledgements}

The writers appreciate the recognition and awards in forms of research grant and fellowship from "Program Penelitian Unggulan Perguruan Tinggi - Kerjasama Internasional BOPTN ITS 2013, Contract number: 013674.169/IT2.7/PN.08.01/2013". All concept and results presented in this paper are parts of research which titled "Coalition Formation Algorithm and Agreement Options Model for Industrialized Building System (IBS) Design Selection". Authors would like to thank to ITS for funding the research and UTM for the collaboration.

\section{References}

Anumba, C. J., Ugwu, O. O., Newnham, L., \& Thorpe, A. (2002). Collaborative Design of Structures using Intelligent Agents. Automation in Construction, 11, 89-103. PII: S0926-5805(01)00055-3.

Besley, T., \& Ghatak, M. (2010). Chapter 68 - Property Rights and Economic Development. Handbook of Development Economics, 5, 4525-4595. Elsevier. http://dx.doi.org/10.1016/B978-0-444-52944-2.00006-9

Bucciarelli, L. (2002). Between Thought and Object in Engineering Design. Design Studies, 23, 219-223. http://dx.doi.org/10.1016/S0142-694X(01)00035-7

Cheng, N. Y. (2003). Review: Approaches to design collaboration research. Automation in Construction, 12, 715-723. http://dx.doi.org/10.1016/S0926-5805(03)00059-1

Chiu, M. L. (2002). An Organization View of Design Communication in Design Collaborative. Design Studies, 23, 187-210. PII: S0142-694X(01)00019-9.

Chiu, M. L., \& Lan, J. H. (2005). Information And In-Formation, Information Mining For Supporting Collaborative Design. Automation In Construction, 14, 197-205. http://dx.doi.org/10.1016/j.autcon.2004.07.011

Dave, B., \& Koskela, L. (2006). Collaborative Knowledge Management - A Construction Case Study. Automation In Construction, 18, 894-902. http://dx.doi.org/10.1016/j.autcon.2009.03.015

Detienne, F. (2006). Collaborative Design: Managing Task Interdependencies And Multiple Perspective. Journal Of Interacting With Computer, 18, 1-20. http://dx.doi.org/ 10.1016/j.intcom.2005.05.001

Ding, G. K. C. (2008). Sustainable construction-The role of environmental assessment tools. Journal of Environmental Management, 86, 451-464. http://dx.doi.org/10.1016/j.jenvman.2006.12.025

Du, J., Jing, S., \& Liu, J. (2011). Creating Shared Design Thinking Process For Collaborative Design. Journal of Network And Applications.

Field, A. (2000). Discovering Statistic using SPSS for Windows. London - Thousand Oaks - New Delhi: Sage Publications.

Gabriel, G. C., \& Maher, M. L. (2002). Coding and Modelling Communication in Architectural Collaborative Design. Automation in Construction, 11, 199-211. PII: S0926-5805 00 00098-4.

Girard, P., \& Robin, V. (2006). Analysis of Collaboration for Project Design Management. Computers in Industry, 57, 817-826. http://dx.doi.org/10.1016/j.compind.2006.04.016

Gross, M. D., Yi-L., D. E., McCall, R. J., Citrin, W. V., Hamill, P., Warmack, A., \& Kuczun, K. S. (1998). Collaboration and Coordination in Architectural Design: Approaches to Computer Mediated Teamwork. Automation in Construction, 7, 465-473. PII S0926-5805 98 00055-7.

Gu, N., Kim, M. J., \& Maher, M. L. (2011). Technological advancements in synchronous collaboration: The effect of $3 \mathrm{D}$ virtual worlds and tangible user interfaces on architectural design. Automation in Construction, 20, 270-278. http://dx.doi.org/10.1016/j.autcon.2010.10.004

Gu, N., Xu, J., Wu, X., Yang, J., \& Ye, W. (2005). Ontology Based Semantic Conflicts Resolution In Collaborative Editing Of Design Documents.Journal of Advanced Engineering Informatics, 19, 103-111. http://dx.doi.org/10.1016/j.aei.2005.05.005 
Ha, J. K., \& Kim, Y. H. (2008). An exploration on on-line mass collaboration: Focusing on its motivation structure. International Journal of Social and Human Sciences, 2, 307-312.

Heising, W. (2012). The integration of ideation and project portfolio management - A key factor for sustainable success. International Journal of Project Management, 30(5), 582-595. http://dx.doi.org/10.1016/j.ijproman.2012.01.014

Huifen, W., Youliang, Z., Jian, C., Lee, S-F., \& Kwong, W-C. (2003). Feature-Based Collaborative Design. Journal of Materials Processing Technology, 139, 613-618. http://dx.doi.org/10.1016/S09240136(03)00502-8

Kalay,Y. E., Khemlani, L., \& Choi, J. W. (1998). An Integrated Model to Support Distributed Collaborative Design of Buildings. Automation in Construction, 7, 177-188. PII: S0926- 580598 00064- 8.

Kamel, N. N. (1999). A unified characterisation for shared multimedia CSCW workspace designs. Journal of information and Software Technology, 41, 1-14.

Kolarevic, B., Schmitt, G., Hirschberg, U., \& Kurmann, D. (2000). An Experiment in Design Collaboration. Automation in Construction, 9, 73-81. PII: S0926-5805(99)00050-3.

Kvan, T. (2000). Collaborative Design: What Is It? Automation in Construction, 9, 409-415. PII: S0926- 580599 00025- 4.

Kvan, T., \& Candy, L., (2000). Designing collaborative environments for strategic knowledge in design. Knowledge-based System, 13, 429-438. PII: S0950-7051(00)00083-6.

Lahti, H., Hakkarainen, P. S., \& Hakkarainen, K. (2004). Collaboration patterns in computer supported collaborative designing. Design Studies, 25, 351-371. http://dx.doi.org/10.1016/j.destud.2003.12.001

Lee, Y. C., \& Gilleard, J. D. (2002). Collaborative Design: A Process Model For Refurbishment. Automation In Construction, 11, 535-544. PII: S0926-5805(01)00064-4.

Leeuwen, J. P. V., \& Fridqvist, S. (2006). An Information Model For Collaboration In The Construction Industry. Journal of Computers in Industry, 57, 809-816. http://dx.doi.org/10.1016 /j.compind.2006.04.011

Levy, Y., \& Ellis, T. J. (2006). A Systems Approach to Conduct an Effective Literature Review in Support of Information Systems Research. Informing Science Journal, 9.

Li, W. D., Lu, W. F., Fuh, J. Y. H., \& Wong, Y. S. (2005). Collaborative Computer Aided Design - Research and Development Status. Journal of Computer Aided Design, 37, 931-940. http://dx.doi.org/10.1016/j.cad.2004.09.020

Lin, C., Standing, C., \& Liu, Y. C. (2008). A Model To Develop Effective Virtual Teams. Journal of Decision Support Systems, 45, 1031-1045. http://dx.doi.org/10.1016/j.dss.2008.04.002

Lottaz, C., Smith, I. F. C., Nicoud, Y. R., \& Faltings, B. V. (2000). Constraint-Based Support For Negotiation In Collaborative Design. Journal of Artificial Intelligent In Engineering, 14, 261-280. PII: S0954-1810(00)00020-0.

Lu, S. C. Y., Cai, J., Burkett, W., \& Udwadia, F. (2000). A Methodology For Collaborative Design Process And Conflict Analysis. Annals of the CIRP, 49(1), 69-73. http://dx.doi.org/10.1016/S0007-8506(07)62898-4

Lu, S. C. Y., Elmaraghy, W., Schuh, G., \& Wilhelm, R. (2007). A Scientific Foundation of Collaborative Engineering. Annals of the CIRP, 56(2), 605-634. http://dx.doi.org/10.1016/j.cirp.2007.10.010

McCall, R., \& Johnson, E. (1997), Using Argumentative Agents to Catalyze and Support Collaboration in Design. Automation in Construction, 6, 299-309. PII: S0926-5805(97)00041-1.

McMahon, M., \& Bhamra, T. (2012). Design Beyond Borders: International collaborative projects as a mechanism to integrate social sustainability into student design practice. Journal of Cleaner Production, 23, 86-95. http://dx.doi.org/10.1016/j.jclepro.2011.10.022

Melchert, L. (2007). The Dutch Sustainable Building Policy: A Model For Developing Countries. Journal of Building and Environment, 42, 893-901. http://dx.doi.org/10.1016/j.buildenv.2005.10.007

Nam, T. J., \& Wright, D. (2001). The development and evaluation of Syco3D: A real-time collaborative 3D CAD system. Design Studies, 22, 557-582. PII: S0142-694X(00)00041-7.

Oztok, M., \& Ordener, N. (2007). Information and communication technologies in collaboration projects via the internet. International Journal of Social and Human Sciences, 1, 195-200. 
Patel, H., Pettitt, M., \& Wilson, J. R. (2012). Factors of collaborative working: A framework for a collaboration model. Journal of Applied Ergonomics, 43, 1-26. http://dx.doi.org/10.1016/j.apergo.2011.04.009

Peng, C. (1994). Exploring Communication In Collaborative Design: Co-Operative Architectural Modelling. Design Studies, 15(1), 19-44. http://dx.doi.org/0142-694X/94010019-26

Ping, C. S., Keung, C. N. Y., \& Ramanathan, M. (2011). Integrated Team Design Process - Successful Stories of Hong Kong MTR Corporation Projects. Journal of Procedia Engineering, 14, 1190-1196. http://dx.doi.org/10.1016/j.proeng.2011.07.149

Plume, J., \& Mitchell, J. (2007). Collaborative design using a shared IFC building model-Learning from experience. Journal of Automation in Construction, 16, 28-36. http://dx.doi.org/10.1016/j.autcon.2005.10.003

Rahmawati, Y., Anwar, N., \& Utomo, C. (2013a). A Concept of Successful Collaborative Design towards Sustainability of Project Development. International Journal of Social, Human Science and Engineering, 7(4), 219-225.

Rahmawati, Y., Anwar, N., \& Utomo, C. (2013b). An Empirical Study toward Current Practices of Collaborative Design in Indonesia. International Conference on Construction and Building Engineering (Iconbuild) 2013, Rahmawati, Y., Utomo, C., \& Anwar, N. (2012a). Collaborative Design in Construction: Past, Present, and Future Research. International Conference of Sustainable Built Environment, 10-12 July 2012.

Rahmawati, Y., Utomo, C., \& Anwar, N. (2012b). Exploring Socio-Technical Factors to Successful Collaborative Design in Product Development: A Review. International Conference of Organization Innovation, 10-12 July 2012.

Rahmawati, Y., Utomo, C., \& Anwar, N. (2013). The Role of Knowledge Management in Collaborative Design to Support Construction Process. $13^{\text {th }}$ International Conference on Quality in Research, 25-28 June 2013. 28-30 October 2013.

Ren, Z., Yang, F., Bouchlaghem, N. M., \& Anumba, C. J. (2011). Multi-disciplinary collaborative building design-a comparative study between multi-agent systems and multi disciplinary optimization approaches. Automation in Construction, 20, 537-549. http://dx.doi.org/10.1016/j.autcon.2010.11.020

Saad, M., \& Maher, M. L. (1995). Shared Understanding In Computer-Supported Collaborative Design. Journal of Computer Aided Design, 28(3), 183-192. http://dx.doi.org/10.1016/0010-4485(95)00025-9

Schmidt, K. (1994). Models and Mechanism of Cooperative Work. Risk National Laboratory Roskilde Denmark.

Simoff, S. J., \& Maher, M. L. (2000). Analysing participation in collaborative design environments. Design Studies, 21, 119-144. PII: S0142-694X(99)00043-5. PII: S0142-694X(99)00043-5

Stasinopoulos, P., Smith, M., Hargroves, K., \& Desha, C. (2009). Whole System Design: An Integrated Approach To Sustainable Engineering. London: Eartscan.

The Natural Edge Project. (2007). Engineering Sustainable Solutions Program Technical Design Portfolio: Whole System Design Suite. Australian Government: Department of the environment and water resources.

Utomo, C., \& Idrus, A. (2011). A concept toward negotiation support for value management on sustainable construction. Journal of Sustainable Development, 4(6), 56-66. http://dx.doi.org/10.5539/jsd.v4n6p56

Utomo, C., Idrus, A., \& Napiah, M. (2009). Methodology for multi criteria group decision and negotiation support on value-based decision. International Conference on Advance Computer Control, Singapore, 22-24 January 2009.

Utomo, C., \& Rahmawati, Y. (2012). The Achievement to Sustainability on Vertical Housing Development through Whole System Design. $3^{\text {rd }}$ International Seminar on Tropical Eco Settlements. $31^{\text {st }}$ October 2012.

Veeramani, D., Tseng, H. P., \& Russel, J. S. (1998). Computer-Integrated Collaborative Design And Operation In The Construction Industry. Automation in Construction, 7, 485-492. PII: S0926-5805(98)00057-0.

Verheij, H., \& Augenbroe, G. (2006). Collaborative Planning Of AEC Projects And Partnership. Automation in Construction, 15, 428-437. http://dx.doi.org/10.1016/j.autcon.2005.06.011

Vivacqua, A. S., Garcia, A. C. B., \& Gomes, A. (2011). BOO: Behavior-Oriented Ontology To Describe Participant Dynamic In Collocated Design Meetings. Journal of Expert System With Application, 38, 1139-1147. http://dx.doi.org/10.1016/j.eswa.2010.05.007 
Wang, L., Shen, W., Xie, H., Neelamkavil, J., \& Pardasani, A. (2002). Collaborative Conceptual Design - State Of The Art And Future Trends. Journal of Computer-Aided Design, 34, 981-996. PII: S0010-4485(01)00157-9.

Wang, N., Chang, Y. C., \& Nunn, C. (2010). Lifecycle assessment for sustainable design options of a commercial building in Shanghai. Journal of Building and Environment, 45, 1415-1421. http://dx.doi.org/10.1016/j.buildenv.2009.12.004

Weinel, M., Bannert, M., Zumbach, J., Hoppe, H. U., \& Malzahn, N. (2011). A closer look on social presence as a causing factor in computer-mediated collaboration. Journal of Computers in Human Behavior, 27, 513-521. http://dx.doi.org/10.1016/j.chb.2010.09.020

Woo, S., Lee, E., \& Sasada, T. (2001). The Multiuser Workspace As The Medium for Communication in Collaborative Design. Automation in Construction, 10, 303-308. PII: S0926- 580500 00046- 7.

Zha, X. F., \& Du, H. (2006). Knowledge Intensive Collaborative Design Modelling and Support Part 1: Review Distributed Models and Framework. Journal of Computers in Industry, 57, 39-55. http://dx.doi.org/10.1016/j.compind.2005.04.007

\section{Copyrights}

Copyright for this article is retained by the author(s), with first publication rights granted to the journal.

This is an open-access article distributed under the terms and conditions of the Creative Commons Attribution license (http://creativecommons.org/licenses/by/3.0/). 